\title{
ЕКОЛОГІЧНА МЕНТАЛЬНІСТЬ УКРАЇНСЬКОГО ЕТНОСУ В ІСТОРИЧНІЙ ПЕРСПЕКТИВІ: СПРОБИ ВИЗНАЧЕННЯ ТА ДОСЛІДЖЕННЯ
}

\author{
Максименко О. О.
}

\section{ВСТУП}

Проблема дослідження екологічної ментальності українців набуває неабиякої актуальності, передусім з огляду на стан навколишнього природного середовища, який не може не викликати занепокоєння. Екологічна криза, що поглиблюється 3 кожним днем, - це значною мірою світоглядна, філософсько-психологічна криза, і пошук шляхів виходу 3 неї варто починати саме зі зміни ставлення людини до природи (яке стає чимраз більше споживацьким і агресивним) та формування нового типу екологічної культури, відмітною рисою якого $\epsilon$ гармонійне співіснування особистості й довкілля. Перефразуючи О. Шпенглера, можна сказати, що такий тип екологічної культури грунтується на здатності людини відчувати живе буття світу, приміряти й пристосовувати його до себе, взаємоузгоджувати власні потреби й устрій довкілля ${ }^{1}$, і він також передбачає певні зміни в екологічній складовій частині ментальності особистості й етносу. Саме тому виникає необхідність вивчення механізмів формування екологічної ментальності українського етносу впродовж його історичного розвитку, виявлення чинників, що впливали на цей процес, а також можливих перспектив розвитку екологічної ментальності в сучасному техногенному суспільстві.

Крім того, зважаючи на невпинний глобалізаційний поступ, варто додати, що проблема дослідження екологічної ментальності є надзвичайно важливою не лише в контексті розвитку українського (або іншого окремого етносу), а й у загальнолюдському плані.

Ступінь розробленості проблеми. Дослідники в царині соціальних і гуманітарних наук давно намагалися проникнути в «душу поколінь», у той моральний ритм, який, за словами Ю. Липи, пливе 3 тисячоліть $\mathrm{i}$ визначає народний характер, формує те соціально типове, що виявляється в поведінці людей як представників тієї чи іншої нації ${ }^{2}$. Аналізу національного характеру українців були присвячені праці

\footnotetext{
${ }^{1}$ Крисаченко В.С. Екологічна культура: теорія і практика : навчальний посібник. Київ : Заповіт, 1996. 352 с.

2 Липа Ю. Призначення України. Вид. 2-ге. Нью-Йорк : Говерля, 1953. 305 с.
} 
видатних учених, істориків та етнографів: В. Антоновича - «Погляди українофілів», М. Грушевського - «Хто такі українці і чого вони хочуть», М. Костомарова - «Две русские народности» ${ }^{3}$, а також відомих представників української діаспори: І. Гончаренка, Н. Григоріїва, О. Кульчицького, щойно згаданого Ю. Липи, І. ЛисякаРудницького, Д. Чижевського та ін. ${ }^{4}$ Серед сучасних дослідників української ментальності та українського національного характеру варто згадати П. Гнатенка, О. Донченко, В. Храмову, а також Дж. Грабовича, О. Грабович, О. Забужко, С. Павличко, О. Стражного. Інші автори спиняються на окремих аспектах української ментальності - ментальності запорізького козацтва (O. Апанович, К. Лащенко), ментальних характеристиках політичної свідомості українців (В. Дем'яненко, I. Поліщук), економічній поведінці (Т. Сфременко), мовних аспектах (Т. Бєсєдіна). Праць, повністю зосереджених на екологічній ментальності українців, поки що немає. Однак у роботах відомих вітчизняних філософів, психологів та українознавців О. Киричука, В. Крисаченка, А. Льовочкіної, Л. Отрошко, В. Сніжка, Є. Сніжко, Ю. Тагліної, О. Таланчук та ін., що присвячені аналізу екологічної свідомості, екологічної культури та екологічної поведінки українців, а також українській ідентичності, міститься чимало положень та фрагментів, пов'язаних iз проблематикою екологічної ментальності ${ }^{5}$. С також доволі цікава стаття А. Шевель «Ментальність українців крізь призму природи» ${ }^{6}$

3 Антонович В.Б. Погляди українофілів. Моя сповідь: вибрані історичні та публіцистичні твори / упор. О. Тодійчук, В. Ульяновський, Київ : Либідь, 1995. С. $143-153$.

Грушевський М. Хто такі українці і чого вони хочуть. Київ: Товариство «Знання» України, 1991. 240 с.

Костомаров М. Дві руські народности. Київ ; Ляйпціг: Українська наклядня, [Б. p.]. URL: http://dlib.kiev.ua/items/show/383 (дата звернення: 20.11.2020).

4 Григоріїв Н.Я. Українська національна вдача. Вінніпег, Манітоба : Українська видавнича спілка в Канаді, 1941. 60 с.

Кульчицький О. Риси характерології українського народу. Енциклопедія украӥнознавства. Загальна частина. У 3-х томах. Т. 2 / гол. ред. В. Кубійович, 3. Кузеля, Мюнхен ; Нью-Йорк, 1949. С. 708-718.

Чижевський Д. Нариси з історії філософії на Україні. Київ : Вид-во «Орій» при УКСП «Кобза», 1992. 230 с.

${ }^{5}$ Крисаченко В.С. Екологічна культура: теорія і практика : навчальний посібник. Київ : Заповіт, 1996. 352 с.

Киричук О.В. Ментальність: сутність, функції, генеза. Тези доповідей та матеріали Міжнародної науково-практичної конферениї «Ментальність. Духовність. Саморозвиток особистості». Київ ; Луцьк: Фундація імені О. Ольжича, 1994. С. 7-20. 
Про нинішню екологічну ситуацію в Україні та у світі йдеться в публікаціях відомих філософів і природознавців, зокрема В. Гьосле ${ }^{7}$, уже згадуваного В. Крисаченка, М. Хилька ${ }^{8}$ та ін. Питання, які порушують ці дослідники, пов'язані з сутністю екологічної кризи, роллю довкілля в особистісному та національному самовизначенні людини, екологічною безпекою, принципами екологічної політики тощо.

У контексті вищевикладеного важливо проаналізувати нагромаджений матеріал, виявити все те, що стосується екологічної ментальності як одного з різновидів ментальності українського народу, і спробувати висвітлити її основні характеристики.

\section{1. Аналіз понять «ментальність» та «екологічна ментальність»}

Поняття «екологічна ментальність» доцільно розглядати як специфічну видову категорію стосовно родового поняття «ментальність», для якого своєю чергою існує кілька дефініцій. Зокрема, у філософії ментальність розуміють як глибинний рівень колективної та індивідуальної свідомості і несвідомого, сукупність схильностей індивіда або соціальної групи діяти, мислити, відчувати й сприймати світ певним чином9 ${ }^{9}$ Утім, це визначення охоплює не всі аспекти ментальності, а лише ті, про які можна зробити висновок (в результаті спостереження, а також інших методів дослідження) в певний момент, «тут» і «зараз». Але ж ментальність формується протягом тривалого часу $\mathrm{i}$, крім того, має шанс змінюватися в майбутньому. На думку авторки, вдалішою є дефініція ментальності, запропонована П. Кононенком: «Ментальність - це глибинний рівень колективної та індивідуальної свідомості, усталена й водночас динамічна сукупність настанов особистості, демографічної групи у сприйманні залежно від етногенетичної пам'яті, культури тощо» ${ }^{10}$.

Колісник О.П. Ментальність, етнічний характер, ідентичність та духовний саморозвиток пересічного українця як чинники долі України. Психологічні перспективи. 2013. Вип. 21. С. 88-117.

Льовочкіна А.М. Основи екологічної психології : навчальний посібник. Київ : Міжрегіональна академія управління персоналом, 2004. 136 с.

Отрошко Л.Г. Феномен природи у світобаченні українців. Украӥнознавство. 2006. № 2. C. 245-253.

${ }^{6}$ Шевель А.О. Ментальність українців крізь призму природи. Наукові праці Чорноморського державного університету імені Петра Могили. Серія «Політологія». 2012. Т. 204. Вип. 192. С. 83-86.

${ }^{7}$ Хёсле В. Философия и экология. Москва : Издат. группа АО «Ками», 1994. 192 с.

8 Хилько М.І. Екологічна безпека України : навчальний посібник. Київ : Київський національний університет імені Тараса Шевченка, 2017. 266 с.

${ }^{9}$ Современная западная философия : словарь / сост. В С. Малахов, В.П. Филатов, 2-е изд., перераб. и дополн. Москва : ТОН - Остожье, 1998. С. 249-250.

${ }_{10}$ Кононенко П.П. Українознавство : підручник для вищих навчальних закладів. Київ : НДІ українознавства, 2005. С. 665. 
Як видно, у цьому визначенні, по-перше, вказується чинник, що впливає на формування ментальності ще 3 далекої минувшини, - «етногенетична пам'ять», по-друге, зазначається можливість певних змін у ментальності етносу, оскільки підкреслюється, що сукупність настанов особистості та групи є «усталеною і водночас динамічною». Водночас до вищенаведеної дефініції хотілося б додати, що ментальність етносу не лише пов'язана зі світосприйманням, а й чинить вплив на розвиток культури й суспільства загалом, тобто має активний характер. Крім того, поняття «демографічна група» можна було б замінити на «соціально-демографічну», оскільки характеристики ментальності зумовлюються не тільки віком, але й соціальним статусом, професійною належністю, освітнім рівнем тощо ${ }^{11}$.

Водночас слід зауважити, що існує також поняття «менталітет», яке нерідко ототожнюється 3 поняттям «ментальність». На думку А. Маленка, обидва ці поняття є універсальними, оскільки вони здатні об'єднати всі галузі знань про людину ${ }^{12}$. Мабуть, це зумовлюється етимологією понять «ментальність» і «менталітет», що віддзеркалює їхній зміст, пов'язаний зі складом мислення людини, специфікою розуміння нею навколишнього світу ${ }^{13}$.

На невизначеність поняття «ментальність» звертав увагу i А. Гуревич, дослідник творчості французької історичної школи «Анналів» ${ }^{14}$, зазначаючи, що «певна розмитість поняття зумовлена самою природою феномена: ментальність всюдисуща, вона пронизує все людське життя, присутня на всіх рівнях свідомості й поведінки людей, а тому так складно їі визначити, ввести в якісь рамки» ${ }^{15}$.

Як система поглядів, оцінок, норм та умонастрою, ментальність формується на підставі конкретних знань і вірувань, наявних у суспільстві,

${ }^{11}$ Кононенко П.П. Українознавство : підручник для вищих навчальних закладів. Київ : НДІ українознавства, 2005. С. 665.

12 Маленко А.С. До питання про ментальність як предмет психологічних досліджень Тези доповідей та матеріали Міжнародної науково-практичної конферениії «Ментальність. Духовність. Саморозвиток особистості». Київ ; Луцьк : Фундація імені О. Ольжича, 1994. С. 111-114.

13 Термін «ментальність» походить від латинського терміна логічного ряду mentalis, mens, mentis - «розумовий», «розум», «думка», «інтелект». 3 англійської мови mentality (синонім - mindset) перекладається як «розум», «інтелект», «склад розуму», «умонастрій» і тлумачиться як спосіб мислення та ставлення до навколишньої дійсності, спосіб її відчування й осмислення.

${ }^{14}$ Уперше поняття «ментальність» 3'явилося у праці Л. Леві-Брюля «Ментальні функції у відсталих суспільствах» (1910), детальну ж розробку цієї категорії пов'язують 3 французькою «Новою історичною школою», або школою «Анналів», основні підвалини якої були закладені ще в 20 -х роках XX ст.

15 Гуревич А.Я. Проблема ментальностей в современной историографии. Всеобщая история: Дискуссии, новые подходы. Вып. 1 / отв. ред. А.О. Чубарьян, В.В. Согрин, Москва : Наука, 1989. С. 75-89. 
а також архетипів колективного несвідомого. Соціокультурний «ген», що визначає культурну належність людини до тієї чи іншої соціальної спільноти або етносу, зумовлює взаємозв'язок не лише індивідуальної й колективної свідомості, а й індивідуального та колективного несвідомого. Колективне несвідоме перебуває глибоко всередині людини як відбиток нагромадженого людського досвіду, до якого особистість звертається в разі необхідності в їі індивідуальному несвідомому. Ці символічні схеми колективного несвідомого, названі швейцарським психологом К. Юнгом архетипами, зазвичай не підлягають теоретичному аналізу чи осмисленню і навіть не усвідомлюються людьми, а залишаються в їхній пам'яті у вигляді закодованої інформації, що закладає відповідні алгоритми соціальної поведінки. Архетипи, що постають як характеристика соціального та акумулюють у собі досвід колективного на рівні підсвідомості, мають відносно латентний характер, який безпосередньо не виявляється. Вони і невловимі, і об'єктивні водночас. Можливо, саме вони виконують функцію збереження і наступності соціокультурної матриці етносу, зумовлюючи певну сталість його ментальності, хоча сталість у жодному разі не означає застиглості. Архетипи, згідно з визначенням відомого філософа С. Кримського, - це ті праобрази, праформи, що закладені в самому історичному бутті культури й розраховані на весь маршрут людської історі1 ${ }^{16}$. Учений переконаний, що звернення до архетипів не означає повернення до минулого, оскільки архетипи тієї чи іншої діяльності - це перекинуті в минуле контури майбутнього, «це культура попереду нас». Тому «Юнг не випадково порівнював їх (архетипи) 3 осями кристала, 3 тими невидимими (не емпіричними) геометричними параметрами, що визначають у розчині фізично зрілі кристалічні фігури» ${ }^{17}$.

Слід зазначити, що поряд із розрізненням загальнолюдської та національної культур розрізняють також загальнолюдські (або загальні) архетипи, до яких належать архетипи Істини, Добра, Краси, та етнічно специфічні праформи культури. Формування етнічної ментальності відбувається в їх переплетенні та взаємодії. На думку авторки, поняття «ментальність» доцільніше застосовувати до соціальної спільноти або етносу (а також націі), ніж до окремої особистості (хоч особистість, так чи інакше, є носієм ментальності певного етносу, нації або соціальної спільноти). Адже ментальність як система поглядів, уявлень і настанов характеризує соціально типове, масове у своїх виявах, що притаманне певній соціальній спільноті загалом і відрізняє іiі від інших, а не

${ }^{16}$ Крымский С.Б. Культурные архетипы, или «знание до познания». Природа. 1991. № 11. С. 72-73.

${ }^{17}$ Там само. С. $74-75$. 
виходить із характеристик, хай навіть і яскраво виражених, окремих іiі представників. Що ж стосується етнічної ментальності, то вона за своєю природою $\epsilon$ «осадом історії даного етносу» ${ }^{18}$, який викристалізувався впродовж багатьох століть, а можливо, й тисячоліть.

Етнос, нація, народ - близькі, але не тотожні поняття. На відміну від поняття «нація», що характеризує етнос на вищому етапі його розвитку 3 акцентом на національній свідомості та певній політичній і державній організації ${ }^{19}$, поняття «етнос» $є$ родовим для будь-якої стадії цивілізаційного розвитку народу і несе спадковість та наступність своїх характеристик із глибини століть. Тому більш адекватним і органічним здається поєднання понять «ментальність» $\mathrm{i}$ «етнос».

А під екологічною ментальністю украӥнського етносу пропонується розуміти ту частину української ментальності, яка: а) визначає цінності, ставлення й норми поведінки та діяльності особистості в системі «людина - природа»; б) виявляється в звичаях, традиціях, обрядах, а також у цілеспрямованій людській діяльності 3 перетворення природного середовища відповідно до своїх потреб; в) зафіксована в прислів'ях, приказках, афоризмах, художніх творах, мистецтві й музиці, а також у нормативно-правових документах (екологічне законодавство, концепції екологічної політики тощо).

Дослідження характеристик екологічної ментальності (як окремої особистості, так і етносу загалом) дає змогу усвідомити причини сучасного стану навколишнього природного середовища і почасти передбачити, що може статися в недалекому майбутньому.

\section{2. Характерні риси екологічної ментальності українців}

\section{1. Вплив середовища проживання етносу на формування його екологічної ментальності. Тісний зв'язок українця 3 рідною землею}

Спроби визначити характерні риси українського народу здійснювалися впродовж усієї історії його буття. Ще літописці Київської Русі давали характеристику різним племенам (у тому числі й слов'янським), що жили на їі землях, а світоглядні основи наших пращурів знайшли своє відображення у «Велесовій книзі», «Літописі Аскольда», дохристиянському фольклорі та міфології, а також Біблії ${ }^{20}$.

${ }^{18}$ Феномен нації: основи життєдіяльності / за ред. Б.В. Попова, Київ : Знання, 1998. C. 146.

${ }^{19}$ Кононенко П.П. Українознавство : підручник для вищих навчальних закладів. Київ : НДІ українознавства, 2005. С. 14, 350.

${ }^{20}$ Там само. C. 23, 44, 115. 
Крім того, в цих джерелах значна увага приділялася природним умовам як важливим чинникам формування української ментальності.

«Літопис Руський» зауважує, що навіть родові назви племенам Київської Русі дала природа: «Слов'яни, прийшовши, сіли по Дніпру і назвалися полянами, а інші древлянами, бо осіли в лісах; а другі сіли межи Прип’яттю і Двіною і назвалися дреговичами; а інші сіли на Двіні і назвалися полочанами - од річки, яка впадає в Двіну і має назву Полота. Слов'яни ж, (що) сіли довкола озера Ільменя, прозвалися своїм іменем - (словенами) ... А другі ж сіли на Десні, і по Сейму, і по Сулі й назвалися сіверянами» ${ }^{21}$.

Істотною особливістю екологічної ментальності (не лише українців, а й будь-якого іншого етносу) $є$ те, що вона не тільки виявляється у ставленні людини до навколишнього природного середовища чи іiі поведінці в ньому, але й формується під впливом довкілля. Ба більше, природа $\epsilon$ одним із вирішальних чинників формування як національного характеру i духовності, так i антропологічних (расових) особливостей індивідів ${ }^{22}$.

Як зазначає В. Сніжко, природа - це широке поняття навколишнього середовища (довкілля), яке оточує людину, воно може бути неосяжним і водночас наближеним до людини. Тобто все, що оточує людину разом із планетою, на якій вона живе, - Природа. У ній немає нічого сталого, все існує в динаміці й розвивається з різною швидкістю і 3 різними наслідками. Людина, усвідомлюючи навколишне середовище, весь час ніби присутня при народженні певних об'єктів. Тому i називає всі об'єкти навколо себе природженими, тобто Природою ${ }^{23}$.

Ще Ж.-Ж. Руссо робив у своїх працях акцент на пріоритетності природної суті людини, а його вчення (географічний детермінізм) ставило в безпосередню залежність від кліматично-геологічних чинників усі явища суспільного життя ${ }^{24}$. Серед комплексу цих чинників французький учений особливу увагу приділяв грунтам, водним ресур-

${ }^{21}$ Кононенко П.П. Українознавство : підручник для вищих навчальних закладів. Київ : НДІ українознавства, 2005. С. 103.

22 Вовк Ф. Антропологічні особливості українського народу. Етногенез та етнічна історія населення Українських Карпат. У 4-х томах. Т. 1. Археологія та антропологія / гол. ред. С. Павлюк, Львів : Інститут народознавства НАН України, 1999. С. 503-534.

23 Екологічне виховання, народне оздоровлення, традиційне харчування в українській концепції національного здоров'я : українознавча монографія / Сніжко В. В. та ін. Київ : Науково-дослідний інститут українознавства, 2007. 440 с.

24 Руссо Ж.-Ж. Педагогические сочинения. В 2-х томах. Т. 1. Эмиль, или О воспитании / под ред. Г.Н. Джибладзе, сост. А.Н. Джуринский, Москва : Педагогика, 1981. 656 с. 
сам і ландшафтам загалом, а також розмірам території, що належить певній державі. Руссо вважав, що характер кліматичних умов визначає життєві потреби людини - в їі, одязі, житлі, паливі тощо. Клімат зумовлює не тільки колір людської шкіри, вид одягу та облаштування житла, а й характер державного устрою, а також тип управління тією чи іншою спільнотою (або етносом).

Під середовищем проживання етносу прийнято розуміти ландшафт і клімат, особливості грунтів і розміри території, картину зоряного неба й корисні копалини, флору, фауну, водойми та інші елементи, що створюють неповторну своєрідність цього середовища, яке впливає на особливості взаємодії етносу з природою. А це своєю чергою пояснює екологічну зумовленість асоціацій, пізнавальних процесів, комунікації, стереотипи поведінки, різноманітні форми суспільної свідомості ${ }^{25}$.

В одній зі своїх праць Л. Гумільов ${ }^{26}$ зазначив, що етнос - це «явище географічне, завжди пов'язане 3 місцевим ландшафтом, який годує адаптований етнос». Зважаючи на це, варто проаналізувати ландшафтні особливості окремих регіонів 3 метою визначення впливу як місцевих, так i регіональних природних комплексів та їхніх компонентів на формування психіки, а також «духовості» (В. Сніжко) української нації.

Ландшафт - це певна частина земної поверхні у вигляді самостійного природного утворення, що передусім характеризується внутрішньою однорідністю та індивідуальною структурою. Це природний чи антропогенний (змінений під впливом діяльності людини) територіальний комплекс, який є генетично однорідною ділянкою (сегментом) ландшафтної сфери (в нашому розумінні географічної оболонки) 3 єдиним геологічним фундаментом, однотипним рельєфом, гідрокліматичним режимом, поєднанням грунтів і біоценозів та характерною для неї морфологічною структурою ${ }^{27}$.

Українська ментальність - це результат відображення специфіки взаємодії українців з природними та геокліматичними умовами існування й співіснування, що склалася історично ${ }^{28}$. Український етнос формувався у

25 Крисаченко В.С. Екологічна культура: теорія i практика: навчальний посібник. Київ : Заповіт, 1996. 352 с.

${ }^{26}$ Гумилёв Л. География этноса в исторический период. Ленинград : Наука, Ленинградское отделение, 1990. 279 с.

27 Екологічне виховання, народне оздоровлення, традиційне харчування в українській концепції національного здоров'я : українознавча монографія / Сніжко В.В. та ін. Київ : Науково-дослідний інститут українознавства, 2007. 440 с.

28 Киричук О.В. Ментальність: сутність, функції, генеза. Тези доповідей ma матеріали Міжнародної науково-практичної конференції «Ментальність. Духовність. Саморозвиток особистості». Київ ; Луцьк : Фундація імені О. Ольжича, 1994. C. 7-20. 
порівняно спокійних природних умовах, а винятково зручне географічне положення наших земель забезпечувало розмаїття природного довкілля, багатство ресурсів. Крім того, територія України немовби відкрита для всіх, як одне велике перехрестя, де перетиналися не лише найважливіші торгові шляхи, а й різні світогляди, геополітичні уподобання, психоетнічні та етноестетичні пріоритети ${ }^{29}$. Певна річ, саме тому інші народи завжди зазіхали на ці землі, які здавалися їм «молочними ріками».

Як зазначав Ю. Липа, геополітичне становище України зумовлювало їі особливе місце в стратегічних планах Німеччини та інших держав Свропи на початку та в середині XX ст. А ще через праукраїнський терен рухався на Схід Олександр Македонський. Подібно до римського імператора Нерона, саме через Україну планував прокладати шлях до Індії, інших країн Азії та Близького Сходу Гітлер ${ }^{30}$. «Великі природні багатства України все принаджували чужих завойовників, котрих рідні краї були природно вбогі, й неначе накликували до експансії на багату Україну», писав основоположник української географічної науки С. Рудницький у праці «До основ українського націоналізму» ${ }^{31}$.

Клімат, географічне середовище, харчування, погодні умови були визначальними чинниками впливу на формування соціальної, культурної та мовної єдності українців, як і всіх інших народів світу, зазначав український політолог О. Бочковський. А в своїй праці «Вступ до націології» дослідник наголошував на тому, що люди, які живуть постійно в Україні, перебувають у духовному контакті зі своєю українською Батьківщиною і мають невичерпне джерело повноцінного життєвого національного існування. Якщо ж цей контакт занепадає і люди денаціоналізуються, то зникає ментально-психологічна основа належності до українства ${ }^{32}$.

Основною ознакою розвитку українського етносу вчений небезпідставно вважав органічний природний зв'язок людей із рідною землею. На цю ознаку вказували й інші відомі науковці, письменники та публіцисти. Зокрема, М. Грушевський у праці «Хто такі українці і чого вони хочуть» зазначав, що «українцями названо людей таких, що добро українського народу й української землі ставили метою свого

29 Екологічне виховання, народне оздоровлення, традиційне харчування в українській концепції національного здоров'я : українознавча монографія / Сніжко В.В. та ін. Київ : Науково-дослідний інститут українознавства, 2007. 440 с.

${ }^{30}$ Липа Ю. Призначення України. Вид. 2-ге. Нью-Йорк : Говерля, 1953. 305 с.

${ }^{31}$ Рудницький С. До основ українського націоналізму. Вид. 2-ге. Відень ; Прага : Український Скиталець, 1923. 164 с.

${ }^{32}$ Бочковський O.I. Вступ до націології : курс лекцій. Регенсбург : Український технічно-господарський інститут, 1947. 136 с. 
життя i про неї хотіли дбати» ${ }^{33}$. І. Мірчук підкреслював, що український народ «усією своєю істотою врісся в ту землю, на якій він працює спредвіку» ${ }^{34}$. М. Костомаров писав, що «на Україні пишається квітами майже чи не кожний двір хлібороба. На Україні плекають лісові дерева, хоч вони і не приносять матеріальної користі, а просто для краси, чого немає в наших північно-східних сусідів» ${ }^{35}$.

Цікавими є міркування щодо ставлення до землі в різних верств українського суспільства, висловлені основоположником «інтегрального націоналізму» Д. Донцовим у праці «Дух нашої давнини». Він звертає увагу на різницю між підвладною верствою і володарською «кастою», яка випливає 3 характеристик їх духу: «Відношення перших - відношення орача до свого лану, відношення других відношення оборонця або здобувця тої землі, як терену експансії меча, без якого нема і праці плуга» ${ }^{36}$.

«Земля», «Вона - земля» - так називаються найвидатніші твори українських класиків - О. Кобилянської та В. Стефаника. «Земля» - це й назва фільму видатного кінорежисера О. Довженка. Такий тісний зв'язок із землею зумовлювала сама природа, як справедливо зауважив О. Кульчицький: «Вчування в процеси природи для хліборобської людности чорнозему є вчуванням у плодючість землі, в ііі лагідність, щедрість і добрість ...» ${ }^{37}$. Географічний аспект, на думку вченого, $є$ одним із вирішальних чинників впливу на психологію українців.

\section{2. Універсалізм, креативність, волелюбність та кордоцентричність}

Про багату та розмаїту природу земель, що сьогодні входять до складу України, писали Гомер, Геродот та інші видатні особистості минулого. Утім, і Гомер, і «батько історії» Геродот звертали увагу на суворість клімату тих країв. Та й у XVII ст., за свідченням французького дослідника Гійома Левассера де Боплана, в Україні лютували морози: «Хоча ці землі знаходяться на тій самій широті, що й

${ }^{33}$ Кононенко П.П., Кононенко Т.П. Освіта ХХІ століття: філософія родинності. Київ : АртЕк, 2001. С. 202.

${ }^{34}$ Мірчук І. Світогляд українського народу. Народна творчість та етнографія. 1996. № 1. C. 22.

${ }^{35}$ Костомаров М. Дві руські народности. Київ ; Ляйпціг : Українська наклядня, [Б. p.]. URL: http://dlib.kiev.ua/items/show/383 (дата звернення: 20.11.2020).

36 Донцов Д. Ідеї провідної верстви у відношенні до землі. Науково-ідеологічний центр імені Дмитра Донцова. URL: http://dontsov-nic.com.ua/ideji-providnojiverstvy-u-vidnoshenni-do-zemli (дата звернення: 20.11.2020).

37 Кульчицький О. Риси характерології українського народу. Енииклопедія украйнознавства. Загальна частина. У 3-х томах. Т. 2 / гол. ред. В. Кубійович, 3. Кузеля, Мюнхен ; Нью-Йорк, 1949. С. 712. 
Нормандія, тут суворіші та холодніші зими. У 1646 р. ... мороз був таким пекучим і лютим, що ми змушені були знятись табором 3 вибраного місця, при цьому втратили дві тисячі воїнів... Мороз убивав не лише людей, а й коней...» ${ }^{38}$. Зрозуміло, що подібні кліматичні умови вимагали від населення міцного тіла й духу, мужності й витривалості.

Однак унікальна українська природа, додавши до суворості, витривалості, працелюбності, мужності цього народу широту світосприйняття та світорозуміння, глибину емоцій і роздумів, зумовила притаманний українському характерові універсалізм. У формуванні цієї риси вирішальну роль відігравало не лише багатство i різноманітність природи, а й цілісність, до якої одвічно прагнуть усі іiі частини $^{39}$. Феномен універсалізму українців - це синтез цілісності й водночас багатоманітності. Чи не найкращий i найпереконливіший приклад - структура й доля українського етносу (і націï), що зазнавала як доцентрових (об'єднання), так і відцентрових тенденцій (поділ, експансія). Навіть за найнесприятливіших обставин виявлялася воля до цілісності терену згідно із законами вічної та цілісної природи. Природа України - одне з унікальних явищ космічної цілісності.

Розмаїття довкілля не могло не вплинути на властиву українцям креативність, із розвитком якої вироблялася певна толерантність, що знаходило свій вияв у становленні як духовних, так і суспільних цінностей. Досвід спілкування з природою, який нагромаджувався у процесі історико-культурного розвитку українського етносу, сприяв постійному тяжінню українців до природи та розумному використанню iii багатств.

Про волелюбність українського народу, його нетерпимість до будьяких форм примусу й тоталітаризму згадували В. Хрущ і О. Хрущ, які вивчали особливості психологічного складу різних етнічних груп Прикарпаття. «3 давніх-давен, - зазначають дослідники, - на високогір'і розселилися люди сміливі, сильні й вільні. Боротьба 3 силами природи, специфічна система виховання, що грунтується на засадах етнопедагогіки, трудових традицій і народних звичаїв, - усе це формувало почуття незалежності і людської гідності» ${ }^{40}$.

${ }^{38}$ Боплан Г.Л. де. Опис України, кількох провінцій Королівства Польського, що тягнуться від кордонів Московії до границь Трансільванії, разом з їхніми звичаями, способом життя і ведення воєн. Київ: Наукова думка; Український науковий інститут Гарвардського університету, Кембридж, Массачусетс, 1990. 256 с.

39 Отрошко Л.Г. Феномен природи у світобаченні українців. Українознавство. 2006. № 2. C. 245-253.

40 Льовочкіна А.М. Основи екологічної психології : навчальний посібник. Київ : Міжрегіональна академія управління персоналом, 2004. С. 67. 
Ще одна риса ментальності українця - емоиійність, яку Д. Чижевський називає «безумовною рисою психічного укладу українця поряд 3 сентименталізмом, чутливістю, ліризмом». Найяскравіше виявляються ці ознаки в естетизмі народного життя і обрядовості ${ }^{41}$. Споконвіку в українському народі живе й поетичний ліризм, віддзеркалюючись у казках i піснях, картинах і літературних творах. «Садок вишневий коло хати» оспівував не лише Тарас Шевченко, а й інші українські письменники: Марко Вовчок, Іван Нечуй-Левицький, Степан Васильченко, по-своєму милуючись красою цих квітучих дерев. Надзвичайно багата, щедра, таємничо-чарівна природа Волині відображає всю універсальність буття й свідомості персонажів «Лісової пісні» Лесі Українки. Через образи Марічки й Іванка змалював безсмертний образ неповторних українців західного регіону в «Тінях забутих предків» М. Коцюбинський. Але якщо в цій повісті вони переважно душевно красиві, ніжні й романтично піднесені в своїй закоханості та ідеальній вірності, то герой оповідання Г. Хоткевича «Гуцул» - це типовий легінь Карпат 3 усіма рисами характеру, що зумовлює їхню етнічно-природну особливість ${ }^{42}$.

У нерозривній єдності 3 природою формувалася й українська релігійність. Як зазначає I. Крип'якевич, в Україні людина віддавна «жила в тісних зв'язках із природою, i як їі господарські заняття, так i весь світогляд єдналися 3 явищем природи»; дохристиянська релігія українця «була культом природи. Головні боги - Дажбог - сонце, Перун - грім, Свиборг - вітер, все це образи Природи» ${ }^{43}$.

Не можна не згадати ще про одну 3 основних характеристик «української душі» - кордочентризм (або кордоцентричність), яка тісно пов'язана 3 емоційністю ${ }^{44}$. Вона означає, що в житті людини, в іiі світогляді провідну роль відіграють радше емоції, почуття або, образно кажучи, потенції людського серця (від лат. cor - «серце»), ніж інтелектуальні сили. Кордоцентричність $є$ основою самого буття, частиною природи українського народу: українець живе, а все його світобачення, поведінка й культурні надбання узгоджуються з притаманним йому кордоцентризмом.

41 Чижевський Д. Нариси з історії філософії на Україні. Київ : Вид-во «Орій» при УКСП «Кобза», 1992. 230 с.

42 Кононенко П.П. Українознавство : підручник для вищих навчальних закладів. Київ : НДІ українознавства, 2005. С. 116.

43 Екологічне виховання, народне оздоровлення, традиційне харчування в українській концепції національного здоров'я : українознавча монографія / Сніжко В.В. та ін. Київ : Науково-дослідний інститут українознавства, 2007. 440 с.

44 Колісник О.П. Ментальність, етнічний характер, ідентичність та духовний саморозвиток пересічного українця як чинники долі України. Психологічні перспективи. 2013. Вип. 21. С. 104-105. 
«Філософія серця» має глибокі витоки. Зокрема, на «серці» зосереджувались Антоній Печерський, Іларіон Русин, Григорій Цамблак, Іван Вишенський, Паїсій Величковський, Памфіл Юркевич. На культуру «серця», тобто почуттів, звертали основну увагу і Григорій Сковорода, і Микола Гоголь, і Пантелеймон Куліш, і Тарас Шевченко. Згідно 3 філософією Григорія Сковороди, людина $\epsilon$ малий світ, «мікрокосмос», бо в «сердечній глибині», безодні криється все, що є в цілому світі. Серце - «осердя» людини, воно виступає духовною субстанцією, що $є$ основою людського буття i джерелом життєдіяльності ${ }^{45}$.

Кордоцентричність українського етносу виявлялася в любові до $n р и р о д и$ та прагненні жити 3 нею в злагоді. «Розумне серце» українця відчувало, що людина - невіддільна частина природи, а «добрий розум» підказував звертатися до іiі мудрості в практичних справах, у творчості й пізнанні. В українській ментальності впродовж віків складався архетип ставлення до природи як до найріднішого, найціннішого, що випливає з виняткової важливості всього природного в житті взагалі.

На жаль, останнім часом штучний чинник навколишнього середовища значно потіснив природний за ступенем впливу на сучасну людину. Українцям вже нечасто випадає нагода милуватися безкраїми степами $\mathrm{i}$ квітучими садами. Здебільшого їм доводиться споглядати одноманітну й незграбну архітектуру типових масивів, а також доволі часто бути очевидцями знищення зелених зон - останніх острівців природи у кам'яних джунглях. У дослідженнях з екологічної та етнічної психології неодноразово зазначалося, що людина, яка змушена споглядати подібні картини, може поступово деградувати, стати тривожною або агресивною, втратити здатність до співчуття (до речі, як тут не згадати В. Сухомлинського ${ }^{46}$, хто стверджував, що в дитини, яка вихована в умовах дефіциту спілкування 3 природою, розвивається емоційна глухота, агресивність у ставленні як до людей, так і до об’єктів природи).

Може, й не варто настільки жорстко пов'язувати сучасну архітектуру з психологією сучасних українців, проте розрив зв'язку 3 природою, споживацьке ставлення до неї та антропоцентричний егоїзм в іiї сприйнятті (природа виключно для людини, а не людина серед природи) призводять до численних негативних наслідків ${ }^{47}$.

45 Чижевський Д. Нариси 3 історії філософії на Україні. Київ : Вид-во «Орій» при УКСП «Кобза», 1992. 230 с.

${ }^{46}$ Сухомлинський В.О. Школа і природа: вибрані твори. В 5-ти томах. Т. 5. Київ : Радянська школа, 1977. С. 536-551.

47 Максименко О.О. Деякі особливості споживацького ставлення до природи. Актуальні проблеми психологї : збірник наукових праць Інституту психології імені 


\section{3. Індивідуалізм, інтроверсивність та магічне мислення}

Цікавих висновків щодо впливу компонентів довкілля, зокрема грунтів, на етнопсихологічні особливості українців доходить М. Гримич ${ }^{48}$. Дослідниця зазначає, що завдяки родючим чорноземам врожай сприймався в народі як величина, що зумовлюється переважно метеорологічними чинниками, які, на думку селян, залежали від волі Всевишнього, а також могли змінюватися від бажання й волі їх самих. Інакше кажучи, особливість українських грунтів сприяла розвиткові магічного мислення українців, що відображається в народній медицині, в багатьох календарних і родинних святах, а також мотивах народних пісень. Наприклад, в українських піснях доволі поширеним $\epsilon$ мотив приворожування. А одним із найдавніших пластів українського фольклору $€$ замовляння - короткі міфологічні усні тексти, які використовували наші пращури в господарстві, для відвертання лиха чи хвороби, а також для чаклування. Наші пращури, крім того, були глибоко переконані, що словом можна позитивно впливати не лише на людину, а й на сонце, воду, землю, вітер, на добру і хижу тварину, на люті стихії, на таємничі природні сили, які переслідують землероба впродовж року.

«Ой морозе-морозеньку, іди до нас куті їсти. Вона зварилася пухкенька, 3 маком та узваром, 3 медом весняним, запашним. Іди, морозеньку... Я відчиняю тобі двері і бачу, як сивий натужний дух холоду квапиться у сіни та до світлиці. Іди, морозе, кутю їсти. Ми чекаємо, вичікуємо. У нас уже й пальці терпнуть від твого тривкого сивого духу. Дух твій іде, а тебе в уявленому образі нема. Отже, ти десь забарився і не поспішаєш до нашої оселі. Як не йдеш ти до світлиці, то не йди і на поля та лани, у річки та долини, до садів, ягідників та озимини», - так замовляли взимку морози, щоб не загинув майбутній урожай.

А ще для гарного врожаю просили дощу:

Іди, іди, дощику,

Зварю тобі борщику

В полив'янім горщику.

Іди, іди, дощику,

Цебром, відром, дійницею

Над нашою пашницею...

Г. С. Костюка АПН України. Т. 7. Екологічна психологія. Київ : Міленіум, 2003. C. 263-269.

Özdemir I. Çevre sorunlarının antroposentrik (insan-merkezli) karakteri. Felsefe Dünyası. 1998. Sayı 27. S. 68-80.

Plumwood V. Environmental culture: The ecological crisis of reason. London : Routledge, 2002. 291 p.

${ }_{48}$ Гримич М. Два виміри національного характеру. Наука і суспільство. 1991. № 8. C. 21-26. 
М. Гримич також підкреслює, що переважання магічного мислення позначилося на психології українського народу, внаслідок чого в нього сформувалися такі риси характеру: передбачливість, обережність, зволікання з виробленням рішень і реалізацією задуманого. Українці зважали на можливі магічні впливи, хотіли їх урахувати i, якщо це можливо, відвернути. Магічне мислення певною мірою притаманне нам і сьогодні, адже нерідко ми звертаємося до ворожок і знахарів, або ж самі вдаємося до різних магічних дій і ритуалів ${ }^{49}$.

Варто зауважити, що явища природи сприймалися й усвідомлювалися українцями за допомогою певних посередників, якими є сонце, земля, дощ, дерева, рослини, тварини, вода, річка, ставок тощо. Український фольклор має багато усталених тваринних і рослинних образів, що символізують певні людські якості та життєві події: барвінок - символ молодості, кохання та шлюбу; волошки - символ святості, чистоти, приязності; виноград - символ радості і краси, створення сім’і; дуб - символ міцного здоров'я, козацької сили, довголіття; мак - символ краси, чарівної сили, що захищає від усякого зла; горох символ сліз, полин - нещасливого життя. Калина $\epsilon$ символом невмирущого роду, дівочої чистоти, жіночої краси. Калина поряд із барвінком широко використовувалася у весільній обрядовості: китицями калини прикрашали весільний коровай, калиновим цвітом чи ягодами оздоблювали гільце. Водночас калинові ягоди, кора, цвіт випробувані народні ліки. Верба - символ води, оберіг, поетичний символ дівчини.

За народними уявленнями, освячені у Вербну неділю гілочки верби набували магічних властивостей. Адже їх використовували замість листя священної у Середземномор'ї пальми, якими зустрічали Iсуса Христа. Цими гілочками вдаряли членів сім'ї, примовляючи: «Будь великий, як верба, а здоровий, як вода, а багатий, як земля». 3 лікувальною метою вербу використовували для купелі та обкурювання, а як оберіг - проти блискавки і нечистої сили. Тарас Шевченко згадує в своєму щоденнику, який писався на засланні, про вербу, що росла у нього на Мангишлаку на городі й біля якої він проводив увесь свій вільний час. Під нею він бачив «дивні сни», напівреальні, напівмістичні, які повертали його додому, до друзів; багато чого з тих снів перейшло у вірші. А парк на Сінній (Львівській) площі у Києві, який він також побачив уві сні, існує і в наші дні ${ }^{50}$.

${ }^{49}$ Гримич М. Два виміри національного характеру. Наука і суспільство. 1991. № 8. C. 21-26.

50 Сніжко В.В., Снєжко Є.В. До постанови питання «Проблеми Природи в системі українознавства». Украӥнознавство. 2003. Ч. 1(6). С. 97-102. 
Деякі сучасні філософи й психологи стверджують, що давня людина обожнювала природу суто через примітивність своїх розумових здібностей, оскільки, не знаючи законів природи, всього лякалася. Проте ця думка $\epsilon$ помилковою. Наші пращурі обожнювали природу, передусім, через відчуття гармонійної єдності 3 нею, поступово виробляючи своє бачення та розуміння світу. Одухотворене, звеличене шанування природи, яке сьогодні, на жаль, $є$ незбагненним, у давні часи було виявом феноменальної психогенетичної якості людини гуманності у ставленні до всього живого ${ }^{51}$, людяності, значну частину якої було втрачено.

Український етнопсихолог В. Скребець, характеризуючи вплив природи на формування української ментальності, виокремлює такі іiі риси: господарський індивідуалізм, загострене почуття власності, інтроверсивність (спрямованість психічної діяльності всередину, у внутрішній світ), працьовитість, любов до краси, що відображається в прагненні прикрасити й урізноманітнити подвір'я, чуйність, доброзичливість, багату уяву, сентиментальність ${ }^{52}$.

Значну увагу проблемі інтроверсивності української вдачі приділяв, зокрема, етнопсихолог В. Янів, який у «Нарисах до історії української етнопсихології» пише: «Українець - це інтровертивна людина, 3 сильним відчуттям свого “я” і бажанням самовияву назовні. Ця спрямованість і вирішує приналежність українського народу до індивідуалістичного культурного циклу. Заглиблений у собі і маючи відчуття гідності, він прямує до повалення всяких обмежень особистої свободи, в тому числі до нівеляції соціальних перегород» ${ }^{53}$. Я. Ярема, автор праці «Українська духовність в іiі культурно-історичних виявах», вказував на позитивні сторони інтроверсивності, наголошуючи, що саме такі люди є творцями культури. Не забуваючи про деякі негативні риси, що є похідними від інтроверсивності, - наприклад, «негативізм у ставленні до зовнішніх умов», схильність до ілюзій, ідеалізація життя, бажання відокремитись («моя хата скраю»), «соціальне незацікавлення» ${ }^{54}$, дослідник звертав увагу на чуйне ставлення українців до чужої біди, їхню потребу допомагати ближньому. Отже, можна зробити висновок, що українська інтроверсивність не $є$ замкненістю в собі,

51 Сніжко В.В., Снєжко Є.В. До постанови питання «Проблеми Природи в системі українознавства». Украӥнознавство. 2003. Ч. 1(6). С. 97-102.

52 Льовочкіна А.М. Основи екологічної психології : навчальний посібник. Київ : Міжрегіональна академія управління персоналом, 2004. С. 69.

53 Янів В. Нариси до історії української етнопсихології. Вид. 2-ге. Мюнхен : Український вільний університет, 1993. С. 88.

54 Ярема Я. Українська духовність в ії культурно-історичних виявах. Перший украӥнський педагогічний конгрес 1935 р. Львів : Рідна школа, 1938. С. 16-88. 
а лише спрямуванням на себе, на свій внутрішній світ і водночас - до Природи-Матері, годувальниці, захисниці, часткою якої українці завжди себе відчували.

Індивідуалізм української ментальності отримав у працях дослідників найрізноманітніші епітети: «вибуялий» (В. Янів, В. Пачовський), «безмежний», «непогамований» (І. Мірчук), «обмежений, мальовничий» (Ю. Липа), «самоізоляційний» (Д. Чижевський), «анархійний» (В. Липинський) тощо. А М. Костомаров у «Двох руських народностях» зауважує, що в суспільному житті в росіян панує «загальність», тоді як в українців «особиста свобода» $є$ найважливішою цінністю.

На підставі проаналізованих історичних та українознавчих матеріалів можна стверджувати, що характерними ознаками екологічної ментальності українців $є$ відчуття тісного зв'язку з рідною землею, або антеїзм (від імені давньогрецького героя Антея, що брав силу від Землі-Матері й якого Геркулес зумів побороти, лише відірвавши від землі), працьовитість, волелюбність, креативність, емоційність, а також індивідуалізм (зокрема господарський), інтроверсивність, схильність до споглядання та мрійництва, магічне мислення. Ці риси визначають ставлення особистості до природного середовища і водночас формуються під його впливом. Однак вони характеризують радше «українця минулого», ніж нашого сучасника. Екологічна ментальність не лише визначає модель поведінки людини в довкіллі, а й формується під його впливом, тому цілком слушно припустити, що всі вище перелічені риси зазнали істотних змін, особливо серед мешканців великих міст. Для того щоб виявити та описати ці зміни, потрібно провести емпіричне дослідження.

\section{ВИСНОВКИ}

1. Ментальність - це складна, багатопланова, відносно латентна (прихована) і водночас об'єктивна характеристика етносу, що зумовлює його соціокультурний та соціально-психологічний «генотип».

2. Екологічна ментальність українського етносу - це частина української ментальності, яка: а) визначає цінності, ставлення й норми поведінки та діяльності особистості в системі «людина - природа»; б) виявляється в звичаях, традиціях, обрядах, а також у цілеспрямованій людській діяльності 3 перетворення природного середовища відповідно до своїх потреб; в) зафіксована в прислів'ях, приказках, афоризмах, художніх творах, мистецтві й музиці, а також у нормативно-правових документах (екологічне законодавство, концепції екологічної політики тощо).

3. Характерними ознаками екологічної ментальності українців, що сформувалися під впливом довкілля, можна вважати: антеїзм (відчуття 
тісного зв'язку з рідною землею), емоційність та кордоцентричність, волелюбність, працьовитість, уміння жити й господарювати в гармонії 3 навколишнім природним середовищем, а також індивідуалізм, інтроверсивність та схильність до магічного мислення. Ці риси перебувають у тісному взаємозв'язку 3 описаними в літературних джерелах (зокрема історичних) ментальними характеристиками українців загалом. Однак цілком імовірно, що вище перелічені характеристики істотно змінилися протягом останніх десятиліть, особливо серед жителів великих міст. Виявити та описати ці зміни можна шляхом емпіричного дослідження.

\section{АНОТАЦІЯ}

На підставі аналізу низки історичних та українознавчих джерел, а також власних міркувань і спостережень авторка дає визначення екологічної ментальності українського етносу та виокремлює ії основні риси. Це, зокрема, емоційність, любов і шанобливе ставлення до природи, інтроверсивність, магічне мислення, господарський індивідуалізм. Утім, більшість цих рис $\epsilon$ радше штрихами до «історичного портрета» пересічного українця, для якого характерним був традиційний, сільський уклад життя. Екологічна ментальність не лише зумовлює модель поведінки людини в довкіллі, а й формується під його впливом, тому цілком слушно припустити, що всі вище перелічені риси зазнали істотних змін, передусім серед мешканців великих міст. Виявити та описати ці зміни - це вже завдання майбутнього емпіричного дослідження.

\section{ЛIТЕРАТУРА}

1. Антонович В.Б. Погляди українофілів. Моя сповідь : вибрані історичні та публіцистичні твори / упор. О. Тодійчук, В. Ульяновський, Київ : Либідь, 1995. С. 143-153.

2. Боплан Г.Л. де. Опис України, кількох провінцій Королівства Польського, що тягнуться від кордонів Московії до границь Трансільванії, разом з їхніми звичаями, способом життя і ведення воєн. Київ : Наукова думка ; Український науковий інститут Гарвардського університету, Кембридж, Массачусетс, 1990. 256 с.

3. Бочковський О.І. Вступ до націології : курс лекцій. Регенсбург : Український технічно-господарський інститут, 1947. $136 \mathrm{c.}$

4. Вовк Ф. Антропологічні особливості українського народу. Етногенез та етнічна історія населення Українських Карпат. У 4-х томах. Т. 1. Археологія та антропологія / гол. ред. С. Павлюк, Львів : Інститут народознавства НАН України, 1999. С. 503-534.

5. Григоріїв Н.Я. Українська національна вдача. Вінніпег, Манітоба : Українська видавнича спілка в Канаді, 1941. 60 с. 
6. Гримич М. Два виміри національного характеру. Наука $i$ суспільство. 1991. № 8. С. 21-26.

7. Грушевський М. Хто такі українці і чого вони хочуть. Київ : Товариство «Знання» України, 1991. 240 с.

8. Гумилёв Л. География этноса в исторический период. Ленинград : Наука, Ленинградское отделение, 1990. 279 с.

9. Гуревич А.Я. Проблема ментальностей в современной историографии. Всеобщая история: Дискуссии, новые подходы. Вып. 1/ отв. ред. А.О. Чубарьян, В.В. Согрин, Москва : Наука, 1989. С. 75-89.

10. Донцов Д. Ідеї провідної верстви у відношенні до землі. Науково-ідеологічний центр імені Дмитра Донцова. URL: http:// dontsov-nic.com.ua/ideji-providnoji-verstvy-u-vidnoshenni-do-zemli (дата звернення: 20.11.2020).

11. Екологічне виховання, народне оздоровлення, традиційне харчування в українській концепції національного здоров'я : українознавча монографія / Сніжко В.В. та ін. Київ : Науково-дослідний інститут українознавства, 2007. 440 с.

12. Киричук О.В. Ментальність: сутність, функції, генеза. Ментальність. Духовність. Саморозвиток особистості : тези доповідей та матеріали Міжнародної науково-практичної конференції. Київ ; Луцьк : Фундація імені О. Ольжича, 1994. С. 7-20.

13. Колісник О.П. Ментальність, етнічний характер, ідентичність та духовний саморозвиток пересічного українця як чинники долі України. Психологічні перспективи. 2013. Вип. 21. С. 88-117.

14. Кононенко П.П. Українознавство : підручник для вищих навчальних закладів. Київ : НДІ українознавства, 2005. 680 с.

15. Кононенко П.П., Кононенко Т.П. Освіта XXI століття: філософія родинності. Київ : АртЕк, 2001. 240 с.

16. Костомаров М. Дві руські народности. Київ ; Ляйпціг : Українська наклядня, [Б. p.]. URL: http://dlib.kiev.ua/items/show/383 (дата звернення: 20.11.2020).

17. Крисаченко В.С. Екологічна культура: теорія і практика : навчальний посібник. Київ : Заповіт, 1996. 352 с.

18. Крымский С.Б. Культурные архетипы, или «знание до познания». Природа. 1991. № 11. С. 70-75.

19. Кульчицький О. Риси характерології українського народу. Енциклопедія українознавства. Загальна частина. У 3-х томах. Т. 2 / гол. ред. В. Кубійович, 3. Кузеля, Мюнхен ; Нью-Йорк, 1949. С. $708-718$.

20. Липа Ю. Призначення України. Вид. 2-ге. Нью-Йорк : Говерля, $1953.305 \mathrm{c}$. 
21. Льовочкіна А.М. Основи екологічної психології : навчальний посібник. Київ : Міжрегіональна академія управління персоналом, 2004. $136 \mathrm{c}$.

22. Максименко О.О. Деякі особливості споживацького ставлення до природи. Актуальні проблеми психології : збірник наукових праць Інституту психології імені Г.С. Костюка АПН України. Т. 7. Екологічна психологія. Київ : Міленіум, 2003. С. 263-269.

23. Маленко А.С. До питання про ментальність як предмет психологічних досліджень. Ментальність. Духовність. Саморозвиток особистості : тези доповідей та матеріали Міжнародної науковопрактичної конференції. Київ ; Луцьк : Фундація імені О. Ольжича, 1994. C. 111-114.

24. Мірчук І. Світогляд українського народу. Народна творчість та етнографія. 1996. № 1. С. 22-33.

25. Отрошко Л.Г. Феномен природи у світобаченні українців. Українознавство. 2006. № 2. С. 245-253.

26. Рудницький С. До основ українського націоналізму. Вид. 2-ге. Відень ; Прага : Український Скиталець, 1923. 164 с.

27. Руссо Ж.-Ж. Педагогические сочинения. В 2-х томах. Т. 1. Эмиль, или О воспитании / под ред. Г.Н. Джибладзе, сост. А.Н. Джуринский, Москва : Педагогика, 1981. 656 с.

28. Сніжко В. Філософія природи в науковому українознавстві. Украйнознавчий альманах. 2012. Вип. 8. С. 68-71.

29. Сніжко В.В., Снєжко С.В. До постанови питання «Проблеми Природи в системі українознавства». Українознавство. 2003. Ч. 1(6). C. $97-102$.

30. Современная западная философия : словарь / сост. В.С. Малахов, В.П. Филатов, 2-е изд., перераб. и дополн. Москва : ТОН Остожье, 1998. 544 с.

31. Сухомлинський В.О. Школа і природа : вибрані твори. В 5-ти томах. Т. 5. Київ : Радянська школа, 1977. С. 536-551.

32. Феномен нації: основи життєдіяльності / за ред. Б.В. Попова, Київ : Знання, 1998. 264 с.

33. Хёсле В. Философия и экология. Москва : Издат. группа АО «Ками», 1994. $192 \mathrm{c.}$

34. Хилько M.I. Екологічна безпека України : навчальний посібник. Київ : Київський національний університет імені Тараса Шевченка, 2017. $266 \mathrm{c}$.

35. Чижевський Д. Нариси з історії філософії на Україні. Київ : Вид-во «Орій» при УКСП «Кобза», 1992. 230 с. 
36. Шевель А.О. Ментальність українців крізь призму природи. Наукові прачі Чорноморського державного університету імені Петра Могили. Серія «Політологія». 2012. Т. 204. Вип. 192. С. 83-86.

37. Янів В. Нариси до історії української етнопсихології. Вид. 2-ге. Мюнхен : Український вільний університет, 1993. 217 с.

38. Ярема Я. Українська духовність в ії культурно-історичних виявах. Периий украйнський педагогічний конгрес 1935 р. Львів : Рідна школа, 1938. С. 16-88.

39. Özdemir I. Çevre sorunlarının antroposentrik (insan-merkezli) karakteri. Felsefe Dünyası. 1998. Sayı 27. S. 68-80.

40. Plumwood V. Environmental culture: The ecological crisis of reason. London : Routledge, 2002. 291 p.

\section{Information about the author:} Maksymenko O. O., Master of Psychology, Leading Sociologist at the Department of Methodology and Methods of Sociology Institute of Sociology of the National Academy of Sciences of Ukraine 12, Shovkovichna str., Kyiv, 01021, Ukraine 